\title{
HISTORY AND ACTUAL STATE OF LEGALIZATION OF AVALANCHE ZONING IN SWITZERLAND
}

\author{
By Hans Frutiger \\ (Eidg. Institut für Schnee- und Lawinenforschung, CH-726o Weissfluhjoch/Davos, \\ Switzerland)
}

\begin{abstract}
Tourism in the Swiss Alpine region has developed rapidly in the last 20 years. Many new routes, transport systems, and tourist resorts have appeared for which the planning and construction have inadequately considered the avalanche danger. The local authorities are responsible for the safety and welfare inadequately considered the avalanche danger. The in permits. Since property values have risen considerably since the second World War, speculation in land that is not safe from hazard has become widespread. This speculation has led to numerous conflicts between property owners and the municipal government as well as between sellers and buyers of land which is later found to have an avalanche hazard. In Swiss law a legal basis is required to prohibit building in unsafe places. This basis did not exist in many Swiss cantons when these fateful developments began. This study will show how the legal basis for avalanche zoning has been developed at the federal, cantonal, and communal levels and what the actual state of jurisdiction is. Of special interest are the "precedents" or "case law" which are presented and discussed in this paper. It also gives definitions of the terms "zone", "avalanche zoning", "avalanche hazard map", and "avalanche zone plan".
\end{abstract}

RÉsumé. Histoire et état actuel de la légalisation suisse concernant les zones d'avalanches et la limitation de la liberté de la propriété foncière. Au cours des 20 dernières années, le tourisme s'est développé extraordinairement rapidement dans les Alpes suisses. De nombreuses voies de communication, remontées mécaniques et stations touristiques ont été créées, pour lesquelles la planification et l'exécution ne respectaient pas assez un éventuel danger d'avalanches latent. Les autorités communales sont obligées de veiller à la sécurité des habitants et des visiteurs. Ceci est spécialement important en regard de la planification locale du territoire et des permis de construction. La valeur des terrains situés à proximité des stations touristiques s'étant accrue par bonds depuis la fin de la deuxième guerre mondiale, on spécula énormément sur ces terres à bâtir, même quand il s'agissait de zones avalancheuses. Cette spéculation aboutit dans beaucoup de cas à des conflits, non seulement entre les propriétaires fonciers et les autorités communales, mais aussi entre les vendeurs et les acheteurs des terrains qui, plus tard, se sont révélés dangereux. Pour prévenir des constructions imprudentes, une base légale est nécessaire. En ce qui concerne le zonage des terrains menacés par des avalanches, cette base manquait au commencement de ce développement qui devait être fatal dans la plupart des cantons. Le présent travail démontre comment cette base légale a été créée en Suisse, et quelle en est la conception juridique aujourd'hui. Les décisions administratives et les jugements des tribunaux discutés dans cet ouvrage sont d'un intérêt tout particulier. En outre, les notions "zone", "zone d'avalanche", "carte du danger d'avalanches" et "plan des zones d'avalanches" sont définies.

Zusammenfassung. Geschichte und derzeitiger Stand der Gesetzgebung zur Lawinenzonung in der Schweiz. Der Tourismus im schweizerischen Alpengebiet entwickelte sich in den letzten 20 Jahren ausserordentlich stark und rasch. Viele neue Verbindungen, Transportanlagen und Siedlungen entstanden, bei deren Planung und Ausführung oft nicht oder zu wenig Rücksicht auf eine allfällige latente Lawinengefahr genommen worden war. Die Gemeindebehörden sind verpflichtet, für die Sicherheit sowohl der Einwohner als auch der Gäste zu sorgen. Dies gilt besonders für die Ortsplanung und die Bewilligung neuer Bauten. Da der Landwert im Gebiet der Touristenplätze seit Ende des zweiten Weltkrieges sprunghaft in die Höhe gestiegen ist, wurde viel mit Bauland spekuliert, welches als lawinengefährdet betrachtet werden muss. Die Spekulation führte zu zahlreichen Konflikten, sowohl zwischen Grundeigentümern und Gemeindebehörden, als auch zwischen Verkäufern und Käufern von Land, welches sich später als lawinengefährdet erwies. Um fahrlässige Bauten verhindern zu können bedarf es einer legalen Basis. In Bezug auf die Lawinenzonung fehlte diese zu Beginn der verhängnisvollen Entwicklung noch in manchen Kantonen. Die vorliegende Arbeit soll zeigen, wie diese Basis erst geschaffen werden musste und aus was für Rechtssätzen sie heute besteht. Von besonderem Interesse sind die Konfliktregelungen durch den Richter. Hier werden alle einschlägigen Gerichtsfälle und Urteile besprochen. Zudem werden die Begriffe "Zone", "Lawinenzonung", "Lawinengefahrenkarte" und "Lawinenzonenplan" definiert.

\section{INTRODUGTION}

After the second World War there were changes in social and economic life which considerably influenced the value of land. The increase in value became especially accentuated in the European Alps because farming decreased whilst tourism increased and thus, on the one hand, former farmland became unoccupied, while on the other hand building sites were badly needed by the expanding tourist resorts. This led to an extremely rapid increase in real-estate prices and the value of Alpine land rose to 20 to 50 times the pre-war level in some 
places. The outcome of that development was an unjustifiable speculation in land that did not exempt avalanche terrain, and this led to conflicts.

In general the public authorities were not equal to this rapid development. The new situation led to juridical problems which had to be solved. The conflicts were mainly between the rights of the land owners and the interests of the local authority, who had to provide for public welfare and the safety of the inhabitants of the commune. The communal and cantonal authorities were not prepared and had no legal basis nor administrative measures available to overcome the rising problems.

The conflicts are, from the legal point of view, of two sorts. They may be either in civil law, i.e. a conflict between a seller and a buyer of a land parcel, or of public law, i.e. a conflict between the owner of land and the local authority. These two kinds of conflicts are distinguished in the List of cases (Table III, p. 32I) by the letters "C"' (civil law) and "P"' (public law).

This critical situation fast became evident when in January and February I95 I the Alpine region experienced two catastrophic avalanche cycles. It was the worst winter for more than a hundred years. The reaction of the public and local officials was first vehement but unfortunately was not pursued long enough for adequate precautionary arrangements to be realized for the future. This is especially true for avalanche zoning, which was badly needed.

Only the Swiss Federal Bureau of Forestry (Bundesamt für Forstwesen) had already in 1952 made proposals for precautionary measures to be taken. These are the Richtlinien über die Durchführung dieses Bundesbeschlusses und Bundesgesetzes vom I 7. Juni 1952 (Switzerland. Laws, statutes, etc., I952[b]), guidelines of the Federal Department of the Interior for the implementation of the two Federal Acts of $195 \mathrm{I}$. These guidelines say that the cantons and the communes should feel induced to adopt avalanche zoning. We shall see later that the reactions of some of the Alpine cantons to that appeal were disappointing. Another avalanche catastrophe, namely that of January i 968 , was necessary to shake up public opinion and to induce the deputies to take action in the cantonal and federal parliaments. In the years I968 to I970 there were nine such interventions (see Table II, p. 320).

The purpose of this paper is to show how the legal and administrative instruments for the control of avalanche hazard, especially avalanche zoning, have been developed in Switzerland. The conflicts arising from hazardous building in avalanche terrain are analysed, and the court and administrative decisions are presented and discussed. It is shown how the legal basis for avalanche zoning had first to be prepared, and how this was done on the cantonal and federal levels of legislation and administration. Of course, a thorough understanding of the typical Swiss situation is not possible if the reader is unfamiliar with Swiss political institutions and Swiss law and administration. The basic aspects are presented in the publications by Huber (1974) and Germann (1950). The Swiss Property Law has been translated into English by Williams ( 1976$)$.

\section{DisASTER PREVENTION IS A DUTY OF THE COMMUNAL AUTHORITY}

"Since she came into existence, Switzerland has been the characteristic country of the communes" (Huber, 1974, p. 16). In some cantons the autonomy of the communes has been preserved to a large extent. To understand the regulation of conflicts it is necessary to remember that this is done on a local level. Of course, the ability to legislate is mainly with the cantons, however these often enact skeleton laws, the power to fix details being delegated to the communes. And in particular administration of the law rests with the communes.

From the beginning it has been the right, but also the responsibility, of the communal authority to function as local police and to guarantee the safety of citizens and of property against any kind of damage or danger. It has a direct responsibility to impose land-use control which will eliminate or minimize danger to life and property due to avalanche hazards. That 
right has been fixed by written statements in some cantonal laws and has thus become law. Canton Bern, for example, adopted the following rules: "The municipality must regulate the local police. The local police are an executive branch of the public administration within the limits of the community and responsible for upholding order and guaranteeing safety against disturbances and dangers brought about by living beings or events. In addition, when specific regulations do not exist for certain cases or when instructions given by the appropriate authorities are not available in time, the local police authorities must decide on appropriate measures themselves" (Bern. Laws, statutes, etc., I917, 1920), and Canton St. Gallen stated: "It is the responsibility of the community council to guarantee safety for citizens and property against any kind of damage or danger, and to uphold order and prevent public disturbance. The community council, acting as the local building police authorities, should prevent or eliminate hazard associated with buildings, since such hazards might be dangerous to public safety and order" (St. Gallen. Laws, statutes, etc., r947).

The right and duty of the communal authority to exercise local police power is called the "general police clause". In a decision of the Swiss Supreme Court (Schweizerisches Bundesgericht) of I 7 February I97I is stated: "The general police clause has the worth of a constitutional principle both of the confederation as well as of the cantons".

At the beginning of ${ }^{1} 9^{6} \mathrm{I}$ the Council of the Commune of Zermatt had applied to the Federal Bureau of Forestry and asked "if it is possible to impose a building embargo on a hazardous zone on the basis of the federal legislation and, if so, what compensation has to be paid and by whom?"' On 16 April I96r the Office of Legal Advice of the Swiss Federal Department of the Interior (Eidgenössisches Departement des Innern) informed the Federal Bureau of Forestry as follows: "The prohibition of building belongs to the building police. In this field the Confederation is not competent. According to art. 3 of the Swiss Federal Constitution (Switzerland. Laws, statutes, etc., 1874) and the art. 702 of the Swiss Civil Code (Switzerland. Laws, statutes, etc., 1907) the cantons are competent for the release of restrictions imposed in the public interest and regarding private interests. The Supreme Court was constantly of the opinion that all restrictions of the rights of property by building or zoning codes that exceed custom need a clear and indisputable cantonal and legal base. The zoning by the commune of open spaces, farmland, sites of hotels and so on, must expressly be provided for by word and meaning of the cantonal law. Restrictions of private rights in property in the public interest only have to be compensated if the use of the land as it has been in the past, is no longer possible in the future. Compensation of land owners of avalanche sites by the Commune of Zermatt would only be necessary where the land already had the character of a building site. Since sites have been designed as avalanche hazard zones because they are frequented, according to the experience of the recent years, rather often by avalanches, the land might only very seldom be classified as a building site".

The Federal Bureau of Forestry then made further efforts to clarify the legal question. In a circular addressed to the Forest Supervisors of the Alpine cantons regarding the avalanche zoning and avalanche cadastre of ${ }_{13}$ August 1962 , the results of the clarification are recapitulated as follows:

"The r 952 guidelines (Switzerland. Laws, statutes, etc., I952[b]) cannot serve as a legal base to prevent building, because the forest law, to which those guidelines refer, does not contain any statement regarding building law. Neither the cantons nor the communes can deny building permits by referring only to the guidelines. Also the Civil Code is no legal pretext. The lawyer sees no possibility of providing the legal basis for avalanche zoning in federal law. The legal basis for the prohibition of building by avalanche zoning has to be sought in cantonal legislation. There is, however, no cantonal law providing for restrictions of the rights of property by communal avalanche zoning. Some cantonal laws, however, provide for a general zoning of the communal territory. And by this it might be possible to solve the problem." 
At that time there already existed in the building code of the Commune of Davos a clause stating: "Building in avalanche prone terrain is prohibited" (Graubünden. Laws, statutes, etc., I96I).

Summarizing what has been described above, we may substantiate the following: The council of an Alpine commune is able, in any case, to prohibit building in avalanche-prone terrain. If there is no special law he can refer to the general police clause. In this case, the council has to pass for every single building application a special enactment denying the building permit. If there is a legal basis permitting avalanche zoning, the council can rely on that basis according to which a general, abstract regulation a priori prohibits building in an avalanche hazard zone and an enactment is not necessary.

A map of avalanche hazard zones is therefore called an avalanche zone plan if avalanche zoning is admitted by law and thus the map is legally valid and is an integral part of the building code. If the legal basis is not present, then we call the map an avalanche hazard map. It then is merely a technical instrument used by the building police and has no legal status. It helps the building commission to speed up decision-making and to rationalize their activities (Frutiger, 1970, p. 269). That distinction was not made until 1975 when the guidelines of the Federal Bureau of Forestry (Switzerland. Laws, statutes, etc., 1975) mentioned that difference.

In the last $\mathrm{I} 8$ years the Eidg. Institut für Schnee- und Lawinenforschung has elaborated detailed avalanche hazard maps for 26 communes. The terrain investigated extends over a surface of $5533^{\circ}$ ha with ${ }_{56} \mathrm{r}$ individual avalanche paths. To that number more avalanche hazard maps which have been compiled by the cantonal forest services and by private planning offices can be added.

But what is the use of these maps if the communal administration is not strong enough to master the situation? In 1971, i9 years after the Federal Department of the Interior had issued the guidelines (Switzerland. Laws, statutes, etc., 1952[b]), the Government of Canton Valais answered an interpellation in the Grand Council of the Valais which said: "In many places (communes) avalanche hazard maps have not received the necessary attention, especially regarding the issue of building permits". It is not only on the local, but also on the cantonal level, that the $195^{2}$ guidelines did not receive the necessary attention as will be shown in the following section.

\section{The CANTONAL BUILDING AND PLANNING LAWS}

Administration in Switzerland relies predominantly upon law and mainly upon special law. There is a principle that administration has to be constitutional, i.e. it must be based on law. Restrictions of the rights of the land owner must expressly be permitted by law. Decisions of the Supreme Court may illustrate that situation. Two cases with similar circumstances were brought before the Supreme Court. In each case the council of the commune tried to keep ski-ing terrain free from being built over. The Bernese commune was successful, since art. 9 of the Bernese Building Code (Bern. Laws, statutes, etc., 1958) allows the commune to zone ski-ing terrain. But the Supreme Court denied the right of the commune of Canton Vaud to do so because the legal basis of the cantonal building code was not strong enough (Vaud. Laws, statutes, etc., I $94 \mathrm{I}$ art. 23-25) to support the right of keeping land free for the purpose of ski-ing, since "ski-ing terrain" was not expressly mentioned in the code. Therefore keeping terrain free from being built over for the purpose of ski-ing was legal in Canton Bern but was not legal in Canton Vaud (decisions of the Supreme Court 8 May I 963 and 31 March 1965).

The rights of the cantons to enact building and zoning codes stem from art. 3 of the Swiss Federal Constitution of 29 May 1874 and from art. 702 of the Civil Code of ro December 1907. These articles read as follows (in translation): "The Cantons are sovereign as far as their sovereignty is not restricted by the Swiss Federal Constitution and they exercise all rights 
which are not assigned to the Confederation" and "It is the provision of the Confederation, the Cantons, and the Communes to restrict the rights of property for the purposes of public welfare as namely the building police ... can".

In spite of bad experiences with the avalanches of January and February $195 \mathrm{I}$ and in spite of the urging of the $195^{2}$ guidelines the legislative activity of most of the Alpine cantons was minimal. Most of the responsible authorities did not realize what disagreeable consequences would arise for the development of Alpine tourist resorts if avalanche hazard was not mentioned in the building and zoning codes.

An inventory of the building and zoning codes of the cantons was compiled by the Institute for Local-, Regional-, and National Land-use Planning (Institut für Orts-, Regionalund Landesplannung) in 1969. The result was disappointing. Of the Alpine cantons Cantons Ticino, Fribourg, Graubünden, Uri, Vaud, Valais, and Bern are mentioned. These cantons have a total of I 829 communes but only 46 I communes, or $25 \%$, had zoning codes at that time.

There are also some good examples. The building and zoning codes of the communes of Davos and of Pontresina, dating from ig November 196 I and 9 January 1964 respectively, prohibit building on avalanche-prone terrain. The only Swiss canton which has a special avalanche zoning law, dating from 26 April 1964 , is Canton Nidwalden (Nidwalden, Laws, statutes, etc., 1964). From 1970 to 1973 five out of the twelve Alpine cantons released new building and zoning laws. The stimulus for that activity may have been the Federal Act of I969 (Switzerland. Laws, statutes, etc., I969) regarding a constitutional basis for land-use planning.

Table I shows the actual status of cantonal building and zoning codes with respect to avalanche zoning. The twelve Alpine cantons were classified according to the following criteria:

Class I. The code does not provide for zoning. "Zoning" means: Separation of portions of the surface of the communal territory for different land use. The separation is shown graphically on a map.

Table I. Gantonal building codes

\begin{tabular}{|c|c|}
\hline Canton & $\begin{array}{c}\text { Code and article of the code regulating } \\
\text { avalanche zoning }\end{array}$ \\
\hline Bern & Baugesetz, art. $3,20,30,3 \mathrm{I}$ \\
\hline Uri & Baugesetz des Kantons Uri, art. I9 \\
\hline Schwyz & Baugesetz, art. $32,33,35$ \\
\hline Obwalden & Baugesetz, art. 20, 22, 24 \\
\hline Nidwalden & Gesetz betreffend die Lawinenzonenpläne \\
\hline Glarus & Baugesetz für den Kanton Glarus, art. 3,4 , I I \\
\hline Freiburg & $\begin{array}{l}\text { Gesetz betreffend die Feuerpolizei und den } \\
\text { Schutz gegen Elementarschäden, art. I, I I } \\
\text { Verordnung betreffend die Feuerpolizei und } \\
\text { den Schutz gegen Elementarschäden, art. I } 7\end{array}$ \\
\hline St. Gallen & $\begin{array}{l}\text { Gesetz über die Raumplanung und das öffent- } \\
\text { liche Baurecht (Baugesetz), art. 7, ro }\end{array}$ \\
\hline Graubünden & $\begin{array}{l}\text { Forstgesetz des Kantons Graubünden, art } 4^{8} \\
\text { Raumplanungsgesetz für den Kanton Grau- } \\
\text { bünden, art I } 8\end{array}$ \\
\hline Ticino & $\begin{array}{l}\text { Legge edilizia cantonale, art I, } 3 \text { I } \\
\text { Regolamento d'applicazione della legge } \\
\text { edilizia, art. I4 }\end{array}$ \\
\hline Vaud & $\begin{array}{l}\text { Loi sur les constructions et l'aménagement du } \\
\text { territoire, art. I, } 19,20,23^{-25}\end{array}$ \\
\hline Valais & $\begin{array}{l}\text { Gesetz über das öffentliche Gesundheitswesen, } \\
\text { art. } 79\end{array}$ \\
\hline
\end{tabular}

(1) "Avalanche paths"; no mapping of avalanche zones.

(2) Subsequent amendment of art. 15 and 16 of the code.

\begin{tabular}{|c|c|c|c|}
\hline \multirow{2}{*}{$\begin{array}{c}\text { Date of } \\
\text { enactment }\end{array}$} & \multicolumn{3}{|c|}{ Class } \\
\hline & I & II & III \\
\hline $\begin{array}{l}7 \text { June } 1970 \\
\text { Io May } 1970\end{array}$ & & & $\begin{array}{l}x \\
x\end{array}$ \\
\hline 30 April I97o & & $\times$ & \\
\hline 4 June 1972 & & & $x$ \\
\hline $\begin{array}{c}26 \text { April 1964 } \\
4 \text { May I952 }\end{array}$ & & $x$ & \\
\hline I 2 November 1964 & & & $\times(\mathrm{I})$ \\
\hline 28 December 1965 & & & \\
\hline 6 June 1972 & & $\times$ & \\
\hline $\begin{array}{c}6 \text { October } 1963 \\
20 \text { May } 1973\end{array}$ & & & $x$ \\
\hline $\begin{array}{l}\text { 19 February } 1973 \\
\text { 22 January } 1974\end{array}$ & & $x$ & $\begin{array}{l}\times \\
\times(2)\end{array}$ \\
\hline $\begin{array}{l}5 \text { February r94I/ } \\
\text { 16 May 1967 } \\
\text { I } 8 \text { November I96I }\end{array}$ & $x$ & $x$ & \\
\hline
\end{tabular}


Class II. Zoning is provided (compulsory) or is mentioned (optional). Avalanche hazard zones, or more generally, natural hazard zones, are not mentioned expressly, however. Other zones that are similar to avalanche zones, like ski-ing terrain, landscape to be protected, and so on are, however, mentioned. This fact allows us to assume that avalanche hazard zones have been forgotten.

Class III. Avalanche hazard zones, or more generally, natural hazard zones, are mentioned expressly (optional) or have to be determined (compulsory).

The table shows that only six out of twelve cantons have zoning codes (Class III without Canton Fribourg) and only half of them mention expressly natural hazard or avalanche hazard zones.

It is possible to hinder careless building indirectly. The $195^{2}$ guidelines already in $195^{2}$ said: "It is of special importance to alert the insurance companies so that they will insure buildings only when they are built in safe places". The regulations dealing with the insurance of domestic property of Canton Graubünden made use of that possibility (Graubünden. Laws, statutes, etc., I973) (Advisory Report Eidg. Institut für Schnee- und Lawinenforschung No. 71.108). Unfortunately the Commune of Samedan disregarded a map of the same insurance company of 16 December 1950 and issued a building permit which was illegal (see Table III, entry I2, p. I8-19). The same insurance company issued "Vorschriften für bauliche Massnahmen au Bauten in der blauen Lawinenzone (Zone mit geringerer Lawinengefahr)" in 1973 (Graubünden. Laws, statutes, etc., 1973). Since this company is a cantonal institution and thus official, these guidelines are compulsory for all buildings and have an official legal effect like a regulation of an authority.

\section{The role of the Federal Administration}

The $195^{2}$ guidelines have already been mentioned in the Introduction. Those guidelines were intended to provide for the application of Federal Acts of 6 and 19 December I95 $^{\mathrm{I}}$ (Switzerland. Laws, statutes, etc., I95 I[d], I952[a]). Both acts are the consequence of the avalanche catastrophes of January and February I 95 I and aimed at more effective avalanche defences. In the debates of the two chambers (Ständerat or Council of States and Nationalrat or National Council) on those acts nobody spoke about avalanche zoning (Switzerland. Laws, statutes, etc., r95 I [a], [b], [c]). It seems that the deputies were not aware of the far-reaching importance of land speculation in avalanche-prone places. The acts mention only the "reparation of the avalanche damage of the winter 1950-51 and the need for increased help for afforestation and avalanche defences". Preventive measures like the avalanche hazard map would have been of most importance at just that time.

It was therefore especially meaningful that the Federal Bureau of Forestry had pointed expressly to that possibility at least in the execution ordinance to those acts. Sections 6 and 7 of chapter III "Measures to be taken" read as follows:

"6. The elaboration of the avalanche zone plan and avalanche cadastre is indispensible if losses of life and property are to be prevented in the future. Experience with the avalanches of the winter 1950-51 allows communal officials to prepare so-called avalanche zoning plans for the territory of the commune. Those zone plans will show the places which are, as far as one can judge, safe from avalanches and where building is permitted.

Building outside the safe zone shall not be permitted as far as building regulations exist. If they are missing, the local government will do all it can to prevent building in the hazardous zone or will at least draw the builders' attention to the threat to a building and its inhabitants.

It is of special importance to interest the insurance companies in insuring only those buildings that are built in safe places. 
The compilation of avalanche cadastres and keeping them constantly up to date is strongly recommended to the cantonal forest offices. The avalanches are recorded on maps and plans at scales of I : Io 000 to I : 50 000. These avalanche cadastres extend over the whole territory of the canton. The avalanche cadastre will be supplemented by the already-mentioned avalanche zone plans.

If those avalanche zone plans and avalanche cadastres are compiled carefully and if they are observed, it should be possible to protect the mountain people from disaster due to imprudent and careless building.

7. The Confederation cannot subsidize avalanche defences for the protection of buildings or resettlements, if, in selecting building sites, no consideration has been made of the avalanche zone plan and the avalanche cadastre or, if those are missing, warnings have been disregarded."

Because the Confederation had no legal rights to encroach on the privileges of the cantons regarding planning and building law, it made itself felt at least in the Federal Forest Law. In the Executive Ordinance to the Federal Forest Law of I October I965 (Switzerland. Laws, statutes, etc., 1965) an abbreviated wording from the guidelines has been taken over in art. 32 .

The above-mentioned statistics of the Institute for Local-, Regional-, and National Landuse Planning and Table I show that the cantons made little effort in the seventeen years between $195 \mathrm{I}$ and 1968 to master the critical situation. In the meantime the bad consequences of land speculation had become evident and in several instances cantons requested that the Confederation intervene. This is stated in the message of the Federal Council to the Federal Assembly concerning a supplement to the Swiss Federal Constitution by the art. 22(iii) and 22 (iv) of I5 August 1967. The reasons for an intervention of the Confederation are cited literally but can be summed up:

"The Confederation shall be authorized to control the prejudicial effects of land speculation. In fact the cantons all have rights to do this but it shall be here left undecided how far they made use of their rights. The instruments of the cantonal public-building regulations would be suitable for controlling the development of our cities and villages. But the cantonal building codes are very different from each other. It will be absolutely necessary that the Confederation prescribes that the cantons adopt those instruments."

The Federal Assembly enacted the supplement to the Federal Constitution on I I December I969 (Switzerland. Laws, statutes, etc., 1969). Two new articles were inserted of which section I of art. 22 (iv) reads as follows:

"The Confederation will legislate the principles of an appropriate land-use planning to be done by the cantons."

The more recent avalanche catastrophe of January 1968 and the avalanche disaster of 24 February 1970, when an avalanche killed 30 persons near the village of Reckingen, induced successive interventions of the deputies in the federal parliament. Deputy Leu presented a postulate on 5 March 1968 by which he asked "if for especially hazardous zones one should stipulate a general prohibition of building". In an opinion expressed to the Federal Bureau of Forestry on 24 May 1968 regarding the above postulate, the Federal Department of the Interior points to art. $3^{2}$ of the execution regulation to the Forest Law and also to the building code of the Commune of Pontresina. At the end the opinion says:

"Finally, with reference to de lege ferenda, the constitutional legalization of the property law which is actually under way may improve the safety of development areas, which was the purpose of the postulate."

Already before that event some cantonal deputies had intervened in different cantonal councils. Table II gives a list of all interventions regarding avalanche hazard zoning. 
TABle II. INTERVENTIONS IN THE PARLIAMENTS

\begin{tabular}{|c|c|}
\hline 1959 & I 7 November. Ruef Postulate, Grosser Rat of Canton Bern \\
\hline 1960 & I3 September. Gertsch Question, Grosser Rat of Canton Bern \\
\hline 1962 & 29 May. Largiadèr Minor Question, Grosser Rat of Canton Graubünden \\
\hline 1968 & 5 February. Hubacher Postulate, Grosser Rat of Canton Bern \\
\hline I968 & 5 March. Leu Postulate, Ständerat \\
\hline $\begin{array}{l}1968 \\
1970\end{array}$ & 6 March. Grünig Postulate, Nationalrat \\
\hline $\begin{array}{l}1970 \\
1970\end{array}$ & 2 March. Bodenmann Minor Question, Ständerat \\
\hline 1970 & $\begin{array}{l}2 \text { March. Lehner Minor Question, Nationalrat } \\
\text { I I March. Brosi Minor Question, Nationalrat }\end{array}$ \\
\hline 1970 & 26 May. Schmid Minor Question, Grosser Rat of Canton Graubünden \\
\hline I970 & 3 June. Grünig Suggestion, Nationalrat \\
\hline & 12 November. Bumann Interpellation, Grosser Rat of Canton Valais \\
\hline
\end{tabular}

On 26 January 1972 the Federal Council presented a proposal containing a draft of a Federal Act concerning urgent measures in the field of land-use planning to the Federal Assembly. The following are translations of extracts from the proposal which refer to avalanche zoning:

"Even before the adoption of the constitutional articles by the Swiss people and the cantons at the vote of 14 September 1969, the Swiss Federal Department of Justice had begun preparatory work for the executive regulations under the law. The risk during the transitional period until the Federal Law on land-use planning becomes effective, makes urgent measures concerning land-use control necessary."

The essential need for such an act undoubtedly was the protection of the landscape (Switzerland. Laws, statutes, etc., I972[a], p. 510). This may be the reason why in the list of zones to be protected there was no mention of avalanche hazard zones. It seems that during the hearings this deficiency was discovered. In this respect the proposal reads as follows:

"Some organizations considered it advisable to pay attention, in addition to environmental protection, to the restriction of building activity in areas endangered by natural hazards. Some memorials would like to oblige the Federal Council to take precedence over negligent cantons and, if necessary, to designate the areas to be protected and act in their place." The Federal Act was passed on 17 March 1972 (Switzerland. Laws, statutes, etc., 1972[b]). With respect to avalanche hazard it reads as follows:

"The Federal Assembly of the Swiss Confederation, relying on art. 22 quater of the Federal Constitution, resolves that: The cantons, without delay, designate the areas, the use of which is provisionally restricted or prohibited for the purpose of the protection of the environment, for recreational purpose, and for protection from natural hazards. Those provisionally protected areas include ... (e) areas which are known to be endangered by natural hazards. The Federal Council supervises the execution of this Act. If the cantons do not designate those areas in due course or if they do not succeed with that Act effectively, the Federal Council will, after unheeded warnings, itself take measures against cantons, communes, and other disloyal bodies."

This Act, as well as the art. 32 of the 1965 Ordinance (Switzerland. Laws, statutes, etc., 1965) are the legal basis which allows the Confederation to intervene in the case of ill-advised and careless building.

These urgent measures, however, are valid only for a limited time. They must be replaced by a federal law. Already on 14 October 1970 a commission of experts had presented a draft of a Federal law on land-use planning which went to hearings at the beginning of $197 \mathrm{I}$. A second draft of 27 October 1971 was delivered at the beginning of November 1971 to the Federal Department of Justice. On 4 October 1974 the bill was adopted by the Federal Assembly. Within the prescribed period a plebiscite was requested and in a vote of the Swiss people of 13 June 1976 the bill was rejected. At present (31 March 1979) a revised draft of the law is being discussed in the Federal Assembly. 
The role of the federal administration is not restricted to legislation. In 1976 the Federal Bureau of Forestry issued a natural hazard map of Switzerland at a scale of 1 : 100000 (Frutiger, 1980). And the Eidg. Institut für Schnee- und Lawinenforschung as the technical adviser of the Bureau of Forestry investigates the physical and technical aspects of avalanche zoning (Frutiger, 1970). In the course of the preparation of avalanche hazard maps of 8-9 November I962, I I-12 April I967, and I9-20 May i 970 legal aspects have also been discussed in each case.

\section{Administrative AND court Degisions}

Table III presents a list of all administrative and court decisions regarding avalanche hazard which have been taken during the last 23 years. These decisions are known as "Precedents" or "Case Law", i.e. they serve to define the law where regulations are missing.

Table III. Administrative and court decisions

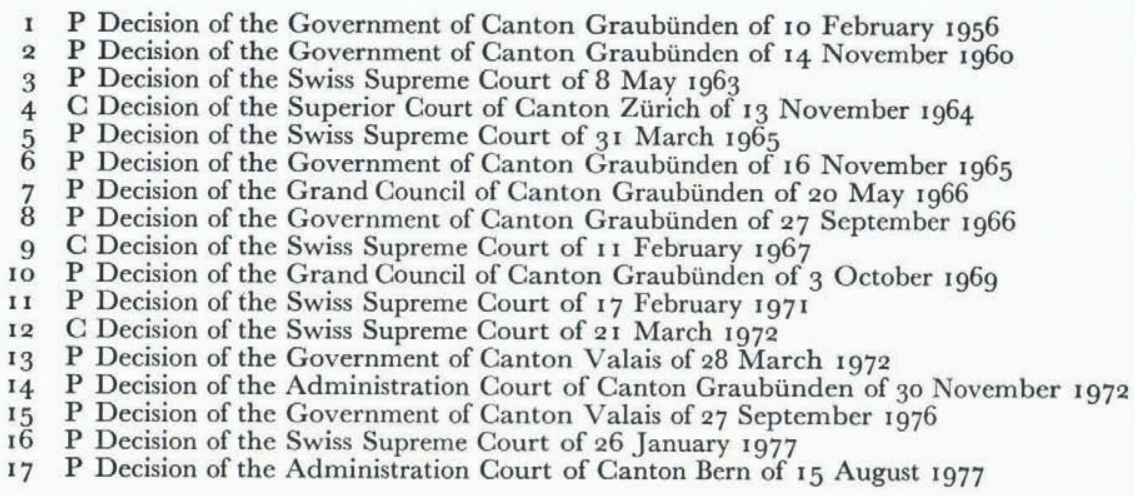

Of these decisions 14 relate to public law $(\mathrm{P})$ and 3 to civil law $(\mathrm{C})$. In 7 cases the denial of a building permit was contested. Two other cases have to do with a building permit for buildings destroyed by avalanches. Four cases are concerned with avalanche zoning. Land owners made appeals against the zoning and contested technical provisions - the question of whether it was hazardous or not-as well as the legal power of the Authority to do the zoning.

The decisions relating to public law show that the communal authority can prevent building in avalanche areas in any case. If an express authorization for avalanche zoning is missing in the cantonal law then the authority can prevent building on the basis of the general police clause.

The author of this article does not agree with some of the arguments referring to the nature of avalanche hazard which can be found in cases I and I4. These say that "One has to consider a normal situation" and "a latent avalanche danger cannot give reasons for prohibition of building".

Of great significance is decision 15 regarding building in a place that is safe but only accessible over avalanche terrain. The decision says that safe access is required.

Avalanche zoning plans have to be sanctioned by the sovereign, i.e. by the Community Assembly. Those plans cannot be "enacted" or "decreed" solely by the Communal Council. They have to be put to the vote (Decision ro).

Of far-reaching importance are three decisions pertaining to civil law. These indicate conformably that a bill of sale of property situated on avalanche terrain can be contested later when the avalanche hazard becomes evident. It can be reasoned that the buyer would not have contracted if he had known that, because of avalanche hazard, he would not obtain a building permit (Federal Law of Obligations, art. 24, section I, cipher 4). That it was an 
erroneous understanding that lead him to contract and that this is a reason to contest the contract. In all three cases the seller had to pay back the full purchase price and had to take back the land. A seller has to consider that he may be charged with committing intentional fraud (Law of Obligations, art. 28, section I) if he knows of a hazard, even if it is only a slight one, and he does not inform the buyer before he contracts with him (Decision 9). These decisions may put an end to an unscrupulous land speculation.

\section{REMARKS}

There remain de lege ferenda some remarks to be made regarding cantonal legislation. First, more systematic legislation should be taken into consideration. The legislation of the Canton Graubünden as well as federal legislation have included rules regarding the building code in their forest laws. This is inappropriate. Canton Valais tries to justify legal prohibition of building in hazard areas by an article pertaining to the Public Health Law and the Canton Fribourg prohibits it by an article of the law concerning the fire police. Restrictions of the rights in property because of avalanche hazard practically always belong to the building and planning codes and therefore all acts to prevent building in avalanche hazardous areas should be contained in those codes.

Second, it is not possible to regulate all aspects of avalanche zoning in a single article (Frutiger, 1970, p. 270-71). The legislation of the Canton Nidwalden is exemplary in that respect and could serve as a model to other cantons.

Third, zoning by three degrees of hazard, namely high grade (red), moderate (blue), and safe (white) is more problematic than laymen may believe. The criterion "avalanches with a mean return period of up to 300 years" (extreme avalanches) is problematic. Such extreme avalanching cannot be understood statistically in a correct manner. Can such strong restrictions of property rights be justified? Would it not be more reasonable to consider only those avalanches which can be understood in a correct manner, let us say, with a mean return period of a hundred years? The demands for safety against avalanche danger should not be higher than for other risks which also offend against public welfare and which are tolerated.

Fourth, the Swiss Federal Land Register secures and protects transactions in property and rights of property. Why should one not make use of this instrument? Already in 1963 the author of this article made proposals when he addressed a memorial to the Federal Bureau of Forestry on 5 January 1963 . He suggested that avalanche hazard zones be shown in the official cadastral maps and that the hazard be made evident in the "description of the property" (Liegenschaftsbeschreibung) and be mentioned in the so-called "annotations" (Anmerkungen) or in the so-called "remarks" (Bemerkungen).

The Chief Federal Forest Supervisor subsequently wrote to the Swiss Federal Bureau of Land Registry on I4 January 1963 . In a letter to the Bureau of Forestry of 13 February 1963 , the Director of the Bureau of Land Registry pointed to the fact that the plans pertaining to the Land Register and the respective notes in that register are only descriptive and therefore have no legal power. Nevertheless the matter was again raised in the article on avalanche zoning in Switzerland (Frutiger, I970, p. 273). It is insufficient when an authority makes reservations when issuing a building permit for a hazard zone and those reservations are only known to the person who demands the permit but will not be known to his assigns. The reservations ought to be stated publicly. They ought to be included in the deeds to the property to alert prospective buyers. The declaration of a property owner that he knows of the hazard is also important with respect to other circumstances (Kuttler, I96o, p. 436) and for those a note in the Land Register is already provided. One should make use of the possibility which art. 962 of the Civil Code offers, namely "the cantons can prescribe that restrictions of the property rights by public law, such as building lines and such like, are to be entered in the register". Only Canton Nidwalden has made use of that possibility with respect to avalanche zoning (Nidwalden. Laws, statutes, etc., 1964). 


\section{Definitions}

\section{Avalanche hazard map}

A large-scale topographic map indicating avalanche hazard (Avalanche Hazard Disclosure). Usually the hazard is shown by different colouring of the areas with a different grade of hazard. For Swiss conditions the "Guidelines for the consideration of avalanche hazard with respect to building and the planning of transport and settlements", provisional issue of July 1975 (Switzerland. Laws, statutes, etc., 1975) have been adopted for the preparation of the map and the evaluation of the different hazard grades. The avalanche hazard map is purely technical and is used by the communal authority as an advisory instrument. It serves also as a basic map for an integral natural hazard (geophysical hazards) map or for the avalanche zone plan (q.v.). Besides those principal purposes it might be used for planning avalanche defences and for the stipulation of contributions to the cost of defences by the owners of the land involved in the hazard.

\section{Avalanche zone plan}

A large-scale map showing the real estate by lots and its relative position regarding avalanche hazard. The avalanche zone plan is based on the avalanche hazard map (q.v.) and, technically, more or less identical with the latter. However, when the avalanche hazard map is incorporated into the land-use planning process of the municipality, it becomes an avalanche zone plan. This process must be based on law, i.e. provisions must have been made in the cantonal law that authorize the municipality to do so. The avalanche zone plan has to be adopted by the sovereign, who, in this case, is the Communal Assembly or it has to be brought to a popular vote. Moreover it has to be sanctioned (ratified) by the cantonal government. It then becomes legal and is part of the zoning and building code of the commune and is used as a fundamental control. It puts limitations of the property rights on those lots endangered by avalanches. These limitations of the right to dispose of the property are of public law. The avalanche zone plan is available for public distribution.

\section{Avalanche zoning}

The extensively used term "avalanche zoning" means preventing an improper use of land. If man is extending his activities into land that is endangered by avalanches and he does not take measures to prevent disasters, he is using land improperly. Essentially, avalanche zoning amounts to avoiding building on avalanche-prone terrain. The performance of that kind of hazard prevention needs technical, legal, and administrative aids and appliances. A technical aid is, for example, the avalanche hazard map (q.v.) which, in turn, is based on the avalanche cadastre and a special method to evaluate avalanche activity at a given place. A legal instrument is the avalanche zone plan (q.v.). A purely administrative aid is the Swiss Federal Land Register by which avalanche activity on a land parcel is made evident officially. As a consequence, avalanche zoning results in public limitation of the disposal of real estate.

\section{Canton}

"Canton" is equivalent to "State"; for example: "Council of States" means the delegates or deputies of the cantons. Of the 26 cantons which constitute the Confederation (q.v.), only 12 lie totally or partly in the Alpine region and thus have avalanche problems.

\section{Confederation}

This is an abbreviation for "Swiss Federal Confederation". The Confederation encompasses 26 cantons (see Huber, 1974). 


\section{REFERENCES}

I. BOOKS AND JOURNALS

Frutiger, H. 1970. Der Lawinenzonenplan (LZP). Schweizerische Zeitschrift für Forstwesen, 121. Jahrg., Nr. 4, p. $246-76$.

Frutiger, H. I980. Swiss avalanche hazard maps. Journal of Glaciology, Vol. 26, No. 94, p. 518-19. [Abstract only; the full version in German is to be published in Interpraevent $1980, \mathrm{Bd} .3$, as part of the proceedings of the symposium held at Bad Ischl, Austria, 8-12 September 1980.]

Germann, O. A. 1950. Grundlagen der Rechtswissenschaft. Bern, Stämpfli \& Cie.

Huber, H. I974. How Switzerland is governed. Third edition. Zürich, Schweizer Spiegel Verlag.

Kuttler, A. 1960. Das Strassengesetz des Kantons Basel-Stadt im Dienste des städtischen Expressstrassenbaues. Schweizerisches Zentralblatt für Staats- und Gemeindeverwaltung, 61. Jahrg., Nr. 18/19, p. 435-50.

Williams, I. 1976. The Swiss Civil Code. Book IV. Law of property. Zürich, ReMaK Verlag.

Zollinger, F. 1976. Die Ausscheidung von Gefahrenzonen. DISP (Institut für Orts-, Regional- und Landesplanung, ETH Zürich), Nr. 42, p. 28-38.

II. Federal statutes

Switzerland. Laws, statutes, etc. 1874. Bundesverfassung der Schweizerischen Eidgenossenschaft vom 29. Mai 1874. Systematische Sammlung des Bundesrechts, I01.

Switzerland. Laws, statutes, etc. 1907. Schweizerisches Zivilgesetzbuch vom 10. Dezember 1907. Systematische Sammlung des Bundesrechts, 2 Io.

Switzerland. Laws, statutes, etc. I95 I [a]. Vormittagssitzung vom 6. Dezember 1951. 6ro5. Forstpolizeigesetz. Abänderung und Ergänzung. Nationalrat. Amtliches Stenographisches Bulletin der Bundesversammlung, 61. Jahrg., p. $863-66$.

Switzerland. Laws, statutes, etc. 1951 [b]. Vormittagsitzung vom 19. Dezember 1951. 6ro5. Forstpolizeigesetz. Abänderung und Ergänzung. Nationalrat. Amtliches Stenographisches Bulletin der Bundesversammlung, 61. Jahrg., p. 934 .

Switzerland. Laws, statutes, etc. $195 \mathrm{I}$ [c]. Vormittagssitzung vom 18. September 1951. 6105. Forstpolizeigesetz. Abänderung und Ergänzung. Ständerat. Amtliches Stenographisches Bulletin der Bundesversammlung, 61. Jahrg., p. $339-48$.

Switzerland. Laws, statutes, etc. 195 I [d]. Bundesbeschluss über die Aufhebung des Abbaues von Bundesbeiträgen an die Kosten für Aufforstungen, Verbauungen und Meliorationen in lawinengefährdeten Gegenden vom 6. Dezember 195I. Bundesblatt, 103. Jahrg., Bd. 3, p. I I I 2-13.

Switzerland. Laws, statutes, etc. I952[a]. Bundesgesetz über die teilweise Abänderung und Ergänzung des Bundesgesetzes betreffend die eidgenössische Oberaufsicht über die Forstpolizei vom 19. Dezember 1951. Sammlung der Eidgenössischen Gesetze, 1952, Nr. 17, p. 339-40.

Switzerland. Laws, statutes, etc. 1952[b]. Eidgenössisches Departement des Innern. Richtlinien über die Durchführung dieses Bundesbeschlusses und Bundesgesetzes vom 17. Juni $195^{2 .}$

Switzerland. Laws, statutes, etc. 1965. Vollziehungsverordnung zum Bundesgesetz betreffend die eidgenössische Oberaufsicht über die Forstpolizei vom 1. Oktober 1965. Sammlung der Eidgenössischen Gesetze, 1965, Nr. 40, p. $86 \mathrm{I}-73$.

Switzerland. Laws, statutes, etc. I 967 . Botschaft des Bundesrates an die Bundesversammlung über die Ergänzung der Bundesverfassung durch die Artikel $22^{\text {ter }}$ und $22^{\text {quater }}$ (Verfassungsrechtliche Ordnung des Bodenrechts) vom 15 . August 1967. Bundesblatt, I 19 . Jahrg., Bd. 2, p. 133-47.

Switzerland. Laws, statutes, etc. 1969. Bundesbeschluss betreffend Erwahrung des Ergebnisses der Volksabstimmung vom 14. September 1969 über die Ergänzung der Bundesverfassung durch die Artikel $22^{\text {ter }}$ und 22 quater (Verfassungsrechtliche Ordnung des Bodenrechts) vom I . Dezember 1969. Sammlung der Eidgenössischen Gesetze, 1969, Nr. 49, p. 1249-51.

Switzerland. Laws, statutes, etc. I972[a]. Botschaft des Bundesrates an die Bundesversammlung zum Entwurf eines Bundesbeschlusses über dringliche Massnahmen auf dem Gebiete der Raumplanung vom 26. Januar 1972. Bundesblatt, 124. Jahrg., Bd. I, p. 501-19.

Switzerland. Laws, statutes, etc. $1972[\mathrm{~b}]$. Bundesbeschluss über dringliche Massnahmen auf dem Gebiete der Raumplanung vom i 7. März 1972. Sammlung der Eidgenössischen Gesetze, 1972, Nr. 12, p. 644-48.

Switzerland. Laws, statutes, etc. 1975. Bundesamt für Forstwesen. Richtlinien zur Berücksichtigung der Lawinengefahr beim Erstellen von Bauten und bei der Verkehrs- und Siedlungsplanung [vom Juli I975]. Provisorische Ausgabe 1975 .

III. Cantonal statutes

Bern. Laws, statutes, etc. 1917. Gesetz über das Gemeindewesen vom 9. Dezember 1917.

Bern. Laws, statutes, etc. I920. Dekret betreffend die Ortspolizei vom 27. Januar 1920.

Vaud. Laws, statutes, etc. 194I. Loi du 5 février r 94 I sur les constructions et l'aménagement du territoire.

St. Gallen. Laws, statutes, etc. 1947. Gesetz über die Organisation und Verwaltung der Gemeinden und Bezirke und das Verfahren vor den Verwaltungsbehörden (Organisationsgesetz). Erlassen am 20. November 1947.

Bern. Laws, statutes, etc. 1958. Gesetz über die Bauvorschriften [vom 26. Januar 1958].

Graubünden. Laws, statutes, etc. I961. Baugesetz der Landschaft Davos vom 19. November 196r.

Graubünden. Laws, statutes, etc. 1964. Bauordnung der Gemeinde Pontresina [vom 9. Januar I964].

Nidwalden. Laws, statutes, etc. 1964. Gesetz betreffend die Lawinenzonenpläne vom 26. April 1964.

Graubünden. Laws, statutes, etc. 1973. Gebäudeversicherung des Kantons Graubünden. Vorschriften für bauliche Massnahmen an Bauten in der blauen Lawinenzone (Zone mit geringerer Lawinengefahr). Ausgabe 1973. 